\title{
WALAWURRU, THE GIANT EAGLEHAWK: ABORIGINAL REMINISCENCES OF AIRCRAFT IN CENTRAL AUSTRALIA 1921-1931
}

\section{R.G. Kimber}

A number of Pintubi and Pintubi-related people ${ }^{1}$ in central Australia and the Western Desert have vivid memories of the first aircraft which visited their country more than half a century ago. This paper records such reminiscences by seven elderly people, gives brief biographical notes on their lives, and assembles documentary evidence on those early flights to date this unique Aboriginal perspective on Australian history.

A number of European explorers ${ }^{2}$ had passed through these areas in the late nineteenth century but apparently impinged very little for their visits are not now recalled by Aborigines. The only European now remembered was Joe Brown, possibly the greatest of all Australian bushmen, who travelled widely in the Western Desert between the 1890s and 1920s and was known to the Pintubi people as Kunki. ${ }^{3}$

The first aeroplane to visit Alice Springs landed on 26 September $1921 .{ }^{4}$ This event was described to me on 26 March 1982 by Mrs Ada M. Wade: ${ }^{3}$

That first plane, it landed right near Billygoat Hill, just this [south] side.

We were very interested. The Aborigines, though, they cleared out. They reckoned it was a Devil-Devil or something. We went down and had a look at it. The Aborigines, they threw their spears at it, some of them.

They went bush. They didn't come back. Not 'til after it was gone. There was only one other flight to Alice Springs prior to 1929, in which year several aeroplanes flew over parts of central Australia and most landed at Alice Springs. ${ }^{6}$ It was not until 1930, however, that Aborigines in remote areas of central Australia and the Western Desert experienced aeroplanes and for many it was their first direct contact with the wider Australian society. Two ventures brought aircraft to central Australia in the early 1930s: the first Mackay Aerial Survey Expedition and the Central Australian Gold Company Expedition, known at the time as the C.A.G.E. Expedition but later as the Lasseter Expedition.

The Mackay Expedition's task was to map from the air those large tracts of the arid regions of Australia that had not been travelled over by Gregory, Giles, Forrest, Warburton and other explorers of the 1850s-1890s. In addition, the expedition aimed to correct existing maps. The detailed planning and

1 Pin tubi is a term used by several tribes or linguistic groupings of Aborigines. All of the people mentioned in this paper use this term and more specific names to identify their local groups. Individual identifications are given in brief biographical notes in Appendix 1. See Giles 1872, Tietkens 1889, Carnegie 1897.

A biography of Brown is in preparation.

Connellan 1979:1.

In 1921 Billygoat Hill was on the outskirts of Alice Springs; today it is in the centre of the town. See Appendix 1, No. 1, for biographical information on Mrs Wade.

- 'Aerial tour of central Australia', The Murray Pioneer (Renmark, S. A.), 19 August 1927:3; Connellan 1979:3-4. See also Madigan 1944: Chapters 10-13. 
efficiency of the operation, together with the fact that there were no mishaps, meant that the achievements were 'solid' rather than spectacular. In contrast, the Lasseter Expedition provided headline news for a year. Its purpose was to locate a gold reef so rich that it might well lift Australia out of the Great Depression. However, almost every misfortune that could have befallen the party did so: there were problems with vehicles, and four aeroplanes either crashed, made forced landings or were damaged in landings. Search parties had to be sent to look for lost airmen. Finally Lasseter died while travelling alone, having believed, as his diary revealed, that he had re-located the fabulous reef. These events ensured that Lasseter's lost gold reef was to become an Australian legend.

Both the Mackay and the Lasseter Expeditions used the Ilpili (Ilbilba, Ilbilla) area in the Ehrenberg Range as a base camp. Ilpili means 'tea-tree' and was a key spring at times of stress for the Aborigines. The Pintubi and Pintubi-related people who visited Ilpili at this time do not usually differentiate today between the two expeditions, and there is a strong tendency for both to be associated with the Lasseter Expedition as Lasseter's name has most often been mentioned by enquirers during the last fifty years. However, a close study of the evidence indicates that the Mackay Expedition had the greatest impact as it was the first group to establish a camp at Ilpili.

\section{The 1930 Mackay Expedition}

In 1930 Australia was in the grip of what was to become known as The Great Depression and there was little money to spend on expeditions. For this reason Donald Mackay's aerial survey work, planned and organized at great personal expense, was hailed by the Federal Government of the day as an act of faith in Australia. Leading politicians farewelled the survey party, including Prime Minister Scullin who stated in his address:

[Mr Mackay] is anxious to assist in the development of civil aviation.... The expedition has been thoroughly organised. A white man with more than 70 camels, 11 natives, 2 Afghans, and an interpreter left Alice Springs almost two months ago to prepare a base camp. The wireless services, navigating and surveying photography, and other aspects of the expedition are all in the hands of experts, and the two pilots who will accompany the expedition have already jointly flown half a million miles without injury to any passenger.'

The advance party included R.H. (Bob) Buck as leader; P. Johns, labourer; Ali Mahomet and Mahomet Bux, cameleers; and probably a man called Joe Oliver as labourer and cook. The Aborigines with the advance party included the interpreter Hawkeye, his wife Tuma on the kitchen staff, 'Tom' and Melinda also on the kitchen staff, Button, Ludwig and Ralph as 
labourers and Hawkeye Junior, a small boy. The expedition proper consisted of the leader Donald Mackay; the pilots, Captains Frank Neale and H.B. Hussey; H.K. Love, radio operator; Commander H.T. Bennett, navigator and surveyor-photographer; P.C. Morrison, journalist, and Joe Oliver (?) who acted as cook for this party as well. ${ }^{8}$

The advance party left in two groups. Bob Buck with several Aborigines, left Alice Springs on Easter Monday. In addition to establishing a camp, this party had to clear an aerodrome and enlarge the well. A week or so later a larger train of 60 camels, in charge of two picturesque old Afghans, Ali Mahomet and Mahomet Bux, left with the main stores, travelling hard, sometimes far into the night, for 19 days to traverse the country... 9

It appears that one of the Afghans travelled ahead of the main camel train, probably to check the water supply, and reached Ilpili a short time ahead of Bob Buck.

Ray Inkamala Tjampitjinpa, ${ }^{10}$ who was approximately ten years old at the time, recalls that he was one of a group of Aborigines camped about half a mile away from the spring, on soft soil beside the creek-bed that runs out from Ilpili. The people were living on rock wallaby, euro, kangaroo, bush turkey, goanna, and the occasional perenti lizard. Mai-i dampers, food-. cakes made from the seeds of wokati (munyeroo), and a plant known as yirria were also eaten. He remembers that camels (which no-one in the group had seen previously) suddenly appeared in the distance. A strange figure (strange because a person wearing clothes had also never been seen) was leading them on foot. Ray and the other Aborigines, who had not been sighted by the distant mamu (devils), were very frightened. They climbed up a stony ridge to the west of the main spring and hid behind rocks. From there they watched the approach of the Afghan and the string of about ten camels. The movements of the strange figure were carefully observed. He tracked the dingo pad to the water like a man, walked like a man and looked about him like a man: the Pintubi decided that he must be human. They noticed that he had power over the mamu, and was unafraid of them. After much close attention it was decided that some of the group should go down and approach close to the strange beings, to determine the nature of the man and beasts.

The Afghan proved friendly, and soon everyone emerged from his or her place of concealment. Ray recalls that his name was Ali-m'omit [Ali Mahomet] and remembers being intrigued by his clothing, the foot-

8 Information compiled from The Argus, 24 May 1930; The Queenslander, 7 July 1930; The Australasian, 2 August 1930; The Brisbane Courier, 1 July 1930; Sydney Morning Herald, 14 July 1937; and Blakeley 1972. However, Clune 1942:254-259 gives Akbar Khan as the name of the Afghan who assisted Ali Mahomet, and indicates that Bob Buck acted as cook for a considerable time.

$9 \quad$ The Queenslander, 7 July 1930.

10 See Appendix 1, No. 2. 
prints left by his shoes, and the features of the man. The camels, initially thought to be mamu and thus feared, were at the same time fascinating. Soon the Pintubi had tasted their first damper made from flour, lollies (boiled sweets kept in a tin), tea, sugar and treacle. They had seen their first drums of petrol and oil. ${ }^{11}$

Shortly afterwards, all members of the advance parties were encamped at Ilpili. The fuel dump contained 2,000 gallons of petrol and supplies of lubricating oil; a camping area with a surrounding brushwood fence was established; and Bob Buck organised the clearing of land for an aerodrome 700 yards long. ${ }^{12}$

Ray Tjampitjinpa and George Tjangala ${ }^{13}$ remember how Pintubi men helped to clear the strip; both - as much as young boys can be imagined assisting - took part in the work. They and indeed several other senior people recall Bob Buck, and some also remember Ali Mahomet. Ray recalled two other men. The first was 'Mutati' (the Pintubi pronunciation of 'Musty'), an Afghan who had a very long string of camels loaded with petrol, oil and food supplies. 'Mutati' (probably Mahomet Bux) was known to be the father's brother of Musty Civic [Sadikh] who today resides in Alice Springs and is well known at Papunya, where he once lived. The other man was ' $\mathrm{Mr}$ Oliver', who hel ped clear the aerodrome; this presumably was the cook 'Joe' mentioned in contemporary newspaper reports. ${ }^{14}$

Hawkeye, the Luritja interpreter, had been important in gaining the cooperation of the Pintubi. Bob Buck now used him to tell the Ilpili people: 'of the coming of two great birds from the bellies of which more white men would come'. Flour, sugar and items of clothing were distributed to maintain the goodwill of the Aborigines. ${ }^{15}$ All the grass, trees and shrubs that had been cleared to make the aerodrome had been stacked in various heaps about the perimeter of the strip and were to be used as signal smokes for the aeroplanes. The first heap to be fired produced a comic incident:

When Bob [Buck] put up his first smoke on ... the earliest possible date of our arrival, it was answered north, south, east and west by Aborigines fires, which would have made it impossible for the machines to pick up the correct position of the aerodrome. 'Bob' sent frantic messages through black interpreters to all the country around that no fires must be lit until the great birds came. ${ }^{16}$

It might be expected that the activities of the advance party would have attracted the attention and interest of these dispersed Aboriginal groups, and initially this was so. However, an incident shortly after the party's arrival

11 Information from Ray Tjampitjinpa (recorded in R.G. Kimber Journal 16 March 1978 and recalled details). This and other Aboriginal accounts ascribe these events to the better-known Lasseter Expedition yet provide circumstantial details fitting documentary evidence about the prior Mackay Expedition.

12 The Australasian, 2 August 1930.

13 See Appendix 1, No.3.

14 R.G. Kimber Journal, 16 March 1978.

13 Sydney Morming Herald, 2 July 1930; The Australasian, 2 August 1930.

16 The Australasian, 2 August 1930. 
caused many Aborigines to leave.

Joe, the cook, ... was sent out to Ilbilba before the others to prepare a landing ground. Joe, according to Mr Mackay, had the best command of bush language he has ever heard, and also a hasty temper. Unfortunately, the day he arrived an irate husband chastised his wife by hitting her on the head with a nulla, and prodding her none too gently with a spear. Joe lost his temper, and the things he did were so fearsome that most of the local inhabitants departed, and, while the expedition was there, remained absent. ${ }^{17}$

Among those who remained at Ilpili were the families whose members included Ray Tjampitjinpa and Johnny Warangula Tjupurrula. ${ }^{18}$ For both, their first memory of an aeroplane was the sound of its approach coming from the east. The only sound they knew that resembled the noise that came from the sky was thunder, yet this noise was not thunder. Then they saw the aeroplane. Walawurru! A giant eaglehawk! Men fitted spears to their woomeras. It came in fast, circled high and then swooped down. Johnny Warangula Tjupurrula saw his father and a few other men throw spears. Then all were running! Ray and Johnny ran in fear; everyone ran in fear. ${ }^{19}$ They 'took to their heels', wrote Commander Bennett, 'and were not seen again for nearly three weeks'. ${ }^{20}$

The sound of the giant eagle, its great size and threatening shadow terrified those who fled and news of the event spread like wildfire. There were some, however, who had been far enough away not to be terrified, only amazed and cautiously interested. They had seen the bird disappearing behind the range, obviously intending to land. ${ }^{21}$ Tapa Tapa Tjangala had been even further away. He had wondered at a far-distant shining speck in the sky, and later discovered that it had been sunlight gleaming on the metal of the banking aeroplane; he also heard how the Pintubi men had thrown spears, and then run for their lives. ${ }^{22}$

Interest eventually overcame fear, and the Pintubi began to return to Ilpili where they examined the manufactured items. Then they dispersed again. Charlie Tjararu Tjungurrayi, at the time a small boy camped at the Kintore Range with his mother, well recalls his father's return from the Ehrenbergs:

The Brisbane Courier, 1 July 1930.

See Appendix 1, No.4.

Ray Tjampitjinpa, R.G. Kimber Journal, 16 March 1978; various accounts 1974-82, Johnny Warangula Tjupurrula. Marshall-Stoneking 198 1:42-43 gives a similar account but inaccurately. The dating of the event as 1966 assumes that Tjupurrula was middleaged instead of a small boy; the information on sites is inaccurate and Johnny was not transported to Papunya by aeroplane as stated.

Sydney Moming Herald, 14 July 1937.

R:G. Kimber Journal, 16 March 1978.

R. G. Kimber Journal, 4 March 1982; it is possible that Tapa Tapa Tjangala glimpsed an aeroplane of a later flight. See Appendix 1, No.5. 
Although he told of flour, tea and sugar, and treacle, it was not these that impressed him so much as waru. He drew attention to the waru (matches) he had carried back to Kintore, then with family watching but unable to comprehend why the little sticks were waru [fire-sticks], he struck one and touched it to a tussock of spinifex. Charlie recalled them all stepping back in fear. How could this be waru? It was mamu [devil] of some kind. His father had not sawed back-and-forth with a woomera edge [to make fire by the traditional friction method]. Thus, as Charlie reiterated, it was waru (matches) that had first impressed. The family had then moved on to Ilpili, and later Hermannsburg, and had come to know the other goods of the white man - most particularly flour, and tea-and-sugar. ${ }^{23}$ It is quite possible that Charlie Tjararu Tjungurrayi's father had experience of both the Mackay and the Lasseter expeditions.

\section{The Lasseter Expedition}

Fred Blakeley was the leader of the Lasseter Expediton, other initial members being 'Harry Lasseter, guide; George Sutherland, prospector and miner; Philip Taylor, engineer; Captain Blakiston-Houston, explorer; and E.H. Coote, pilot ${ }^{24}$ In addition Fred Colson, bushman and transport-driver, Mickey, the Aboriginal guide, Pat Hall, pilot, and Paul Johns, camel-man and dogger, were to join the party on the way to or at Ilpili. Later, among others involved who are significant to this paper, were the pilots Pittendrigh and Hamre who made a forced landing near Haasts Bluff, and Flightlieutenant Eaton, leader of the search party for these two men. ${ }^{23}$

The fact that the Thornycroft truck of the Lasseter Expedition used the camel track of the supply teams of the Mackay Expedition as a guide to Ilpili, and occupied the Mackay camp-site and aerodrome only two months after the Mackay Expedition's departure, ${ }^{26}$ helps explain why Pintubi have tended to link the two ventures in their reminiscences of the expeditions. The expeditions are also associated because Bob Buck was involved with both. He was in charge of the building of the Mackay camp and aerodrome, and he also sent his camel team out to Ilpili while the Lasseter Expedition was based there. The purpose of this journey was to retrieve all empty fuel drums: these were later cut and flattened to provide an iron roof and walls for his home. Furthermore, Bob Buck's name is inextricably linked with Lasseter's as it was he who located Lasseter's body in its shallow Aboriginal-made grave, and who brought in to Alice Springs news and evidence of his death. ${ }^{26}$ The major reason why the two expeditions are confused appears to be the fact

\footnotetext{
R.G.-Kimber Journal, 4 March 1982,-quoted-directly. See Appendix 1, No.6. Idriess 1969:4.

See Coote 1934:Chapters 21-25, Blakeley 1972: Chapters 3-4, for details of personnel. Blakeley 1972:45,57.

Blakeley 1972:143-145; Idriess 1969: Chapter 28.
} 
that prospectors, miners, adventurers, writers, and film and television producers questioning Pintubi between 1931 and 1982 have only been interested in the legend of Lasseter and his supposed gold reef and not Mackay's survey.

It seems probable that after the departure of the Mackay Expedition from Ilpili the Pintubi had moved east to the Mount Liebig area, towards the country from which they perceived the European food supplies, clothing and other interesting items had come. Blakeley recorded what appears to have been an unusual concentration of Aborigines near the mountain:

We were late in starting out... [in the] morning, and the going was slow, but a most remarkable sight appeared just after we started. From every direction we could see smoke-signals going up. Before we started there was not a sign of one, but as soon as the old Thorny [Thornycroft truck] got into low gear, up they went. ${ }^{28}$

Accounts confirming that Pintubi observed the truck and the men of Lasseter's Expedition have been given to me several times between 1972 and 1982 by George Tjangala and Nosepeg Tjupurrula. ${ }^{29}$ It seems that in the Mt Liebig area and further west they remained out of sight, content merely to watch the progress of the vehicle. As a result, it was not until the members of this Expedition were encamped at Ilpili that the Europeans first saw Aborigines. The first Aboriginal to visit the camp was a man wearing an old hat who asked for food and matches. A little later his wife came forward and, as she also asked for matches, Blakeley reasonably assumed that they previously had been in contact with the Mackay Expedition. ${ }^{30}$

During a probe to the west the party was kept under surveillance by Aborigines although they again did not show themselves. Blakeley commented that they 'did a lot of talking on the air with their smokes'. ${ }^{31}$ Upon the Expedition's return to Ilpili, the old Aboriginal who had first met them again asked for various goods, and soon other families came to visit the camp. Their interest in Europeans and their manufactured goods was reciprocated by Blakeley's interest in their reactions:

They showed more interest in Phil [Taylor] than any of us; he had on shorts and sports singlet and was burnt almost as dark as these fellows. They walked around him and had a good look at him. Phil had a fair amount of black hair on his legs and this seemed to cause much amusement; they had clean legs and only very few hairs on the chest... .

We had a tin of lollies, so gave the kiddies a handful each. I had to show them what they were for. I took one and put it in my mouth and the little fellow slowly put one in his mouth, at the same time watching his

28 Blakeley 1972:45.

29. See Appendix 1, No.7. Nosepeg Tjupurrula's name became nationally known in the 1950 s- 1960 s through the Pintubi patrols. Details of his character and work are given by Long (1964) and Lockwood (1964).

30 Blakeley 1972:77-79.

31 Blakeley 1972:90-91. 
father. It was great to see the surprised look on his face when he tasted it... . The big truck seemed to fascinate... [the boys]. Theywere interested in the wheels and both put their fingers in the tread of the tyres and yabbered away to each other, the big chap pointing to the ground. The little chap would poke his finger in the imprint and both looked along the track of the wheels, pointing the way the truck had come. They had evidently seen our tracks and seemed quite delighted to find out what made the track. Phil lifted the bonnet to show them the engine, but the part they were interested in was the bonnet's movement, it seemed to please them. ${ }^{32}$

Blakeley also recorded Pintubi reactions to the lighting of matches, the use of a looking glass and spoons, and their first experiences with boiling water and the taste of sandwiches. ${ }^{33}$

It seems clear that the Pintubi made a rapid and fearless adjustment to European visitors and their manufactured goods. At least some of the assembled Pintubi had become familiar with aeroplanes while at Ilpili during the previous expedition's visit. Given the number and wide range of the Mackay Expedition's flights it is probable that most Pintubi had now seen at least one aeroplane fly overhead, and that all now understood they need not be afraid. This seems to be the most reasonable explanation of the fact that neither Coote nor Blakeley reported signs of fear when the Lasseter Expedition's aeroplane finally arrived at Ilpili. ${ }^{34}$

The day after the arrival of a very small aeroplane, Hall (the pilot while Coote was recuperating from an injury) and Lasseter flew a south-westerly search course. Blakeley was not at all impressed with the irresponsible 'fun' Hall and Lasseter had with Aborigines they sighted during the flight. The fearful Aboriginal reaction, whether they had previously had close experience of aeroplanes or not, is entirely understandable. Blakeley wrote:

[We] found where two natives had been sitting near a fire. Harry [Lasseter] had told us about this fire and how he and Hall had seen two natives standing near it. Hall had banked sharply and swooped down low over them, and the wind from the plane covered them with dust and sand. I could see their tracks in the sand where they had run, and I could also see how close the plane had come down over them - their footprints were almost blown out for about 50 yards. ${ }^{33}$

A much friendlier attitude prevailed when, a little later, Coote flew to Hermannsburg Mission:

Hundreds of black children were lined along the aerodrome, and, as I gave the engine short bursts, taxi-ing to the mooring pegs, they ran in all directions. When the engine was just ticking over they came up to the machine again. ${ }^{36}$

32 Blakeley 1972:109, 109, 110.

33 Blakeley 1972:110-111; see also Coote 1934:160-161 for Aboriginal interest in a rocket and matches.

34 Coote 1934:146-147; Blakeley 1972:127-128.

35 Blakeley 1972:133-134.

36 Coote 1934;183-184. 
The final note on the ill-fated Lasseter Expedition, insofar as it concerns the Ilpili area, occurred when Pittendrigh and Hamre had to make a forced landing north of Haasts Bluff. Flight-lieutenant Eaton, in charge of the search for the missing airmen, made full use of all Aboriginal reports of sightings. The key early evidence, quoted by Coote, was:

that a wild tribe of natives had seen an aeroplane, 20/12/30, flying in a westerly direction eight miles north of Ilbilla ..., and that a black boy from Hermannsberg [sic] had seen the aircraft at about 1230 hours on 20/12/30 at a spot about 12 miles E.S.E. of Ilbilla flying in an E.N.E. direction.... From this information it was decided that Pittendrigh had failed to locate Ilbilla, had made a wide circle around the Ehrenberg Range, and had then endeavoured to return to Alice Springs via outward route, had run out of petrol; and had been forced to land in some spot in

MacDonnell Ranges north of Hermannsburg.

Other Aboriginal evidence from Hermannsburg and Haasts Bluff areas confirmed this information and the search was successful, the men being rescued on 11 January $1931 .{ }^{37}$

The Pintubi of the Ehrenberg Range and surrounding country, whose contact with wider European society had been extremely limited; adjusted remarkably well to the presence of the Mackay and Lasseter Expeditions in a very short time. In a little over six months their attitude had changed from one of understandable terror at the initial arrival of giant mamu eaglehawks, to one of acceptance and understanding such that they were able to give substantial assistance in a search for two missing airmen.

\section{The Consequences of Contact}

Some Pintubi-related people had migrated to the Hermannsburg and Haasts Bluff area in 1929 following the severe drought that prevailed for most of the 1920s. This migration, and reports of the Mackay Aerial Survey Expedition in mid-1930, prompted two very different groups of outsiders to make contact with Pintubi of the Ehrenberg Range. Firstly there were missionaries from Hermannsburg in 1930 and $1931,{ }^{39}$ and secondly, members of the Adelaide University Expedition in 1932.40 These two groups, for entirely different reasons, promoted the migration of Pintubi eastwards to the Mt. Liebig area.

Following the Lasseter Expedition wild rumours drew prospectors to the Ehrenberg Range, with disastrous consequences for Pintubi remaining in this region. In 1934 the Aborigines' Friends' Association noted that:

The Ilbilla tribe of Aborigines ... are greatly perturbed and distressed

Coote 1934:239-246 and end-map.

Albrecht 1977:46-47.

Albrecht 1977:48-53.

40 See Tindale 1974: Plates 60-67. 
over the loss of their supply of fresh water, caused, it is considered, by some prospectors searching for Lasseter's lost reef interfering with their ancient soak ... rendering it useless. ${ }^{41}$

The late Paddy Tucker, prospector and dogger, told me that he had arrived at Ilpili shortly after prospectors had dynamited the spring; it was 1932 and for a short but critical time the spring dried up. In 1934 the Rev. F.W. Albrecht wrote:

The disappearance of the Ilbilla waterhole has been a severe blow to the tribe concerned, as the bushtucker of the natives, growing in the Ehrenberg Ranges, is no longer available to the Aborigines, nor can Ilbilla be any longer used as a resting place for people going through to the Kintore Ranges. The loss of the soak has entailed much hard ship on the natives concerned, who are now at their wits' end to know where to locate themselves. It is considered that the best course to pursue under the circumstances is to seek for a reserve for this tribe, in the vicinity of Haasts Bluff, so as to secure for these Aborigines a supply of food and water. ${ }^{42}$

In 1937 grazing licences in the area were revoked and in 1941 the Haasts Bluff Aboriginal Reserve was declared. ${ }^{43}$

It is clear, therefore, that the arrival of aeroplanes and the support services associated with them, dramatic though these were at the time, merely presaged greater change in the lives of the people of the Ehrenberg Range. It was not until 1976 that government support for the "homeland movement' at last enabled regular travel back to Ilpili by Ray Tjampitjinpa, Johnny Warangula Tjupurrula, George Tjangala, Nosepeg Tjupurrula and other Pintubi people who had been both encouraged and forced to migrate eastwards in the early $1930 \mathrm{~s}^{44}$

ALICE SPRINGS, N.T.

4 Aborigines' Friends Association 1934.

12 Aborigines' Friends Association 1934:16-18.

43 Albrecht 1977:54.

44 See the B.B.C. film 'Desert Dreamers', filmed in October 1976 and released in 1977, for a record of an important homeland visit prior to the provision of facilities. 


\section{APPENDIX 1}

\section{Biographical Notes}

1 Mrs Ada M. Wade was born at Arltunga, $100 \mathrm{~km}$ east of Alice Springs, in 1909. She is fluent in the Aranda language and recalls with pride her Welsh father and Arabanadescent mother. Her great-grandmother was an Arabana woman from the Peake area of South Australia. The Smith family left Arltunga when Ada's father died in 1914 and, driving their flock of goats before them, walked in to Alice Springs. Ada and several brothers and sisters, including Jean (Mrs Jack Shaw), were among the first students at the first school in Alice Springs, where their mother Mrs Topsy Smith was assistant to Mrs Ida Standley, the teacher.

2 Ray Inkamala Tjampitjinpa is the key owner figure for Ilpili. He was born c. 1920. Both his parents died as a result of introduced diseases when he was still a boy, and he was adopted by an Inkamala family at Hermannsburg. He has an excellent knowledge of the Ilpili area and country for a radius of almost $100 \mathrm{~km}$. He is a Maialtjara man, but also uses the term Matutjara.

3 George Tjangala has very strong ties with the Kintore Range country, west of the Ehrenberg Range. He was born c. 1920 and has an excellent knowledge of his own Maiatjara country as well as Winanpa country to the south and Maialtjara to the north. Johnny Warangula Tjupurrula strongly differentiates Maialtjara country from that of the 'inside' Pintubi further west. Although he has strong ties with Ilpili, his key country is approximately $80 \mathrm{~km}$ north-westerly from the Ehrenberg Range. He has exceptional knowledge of the country north of the Ehrenbergs because al though he migrated east to Hermannsburg in the early 1930s, he travelled extensively by camel in his own country thereafter. He was born c.1922.

5 Old Tapa Tapa Tjangala was born c.1912, and is the senior man of authority in the Kintore Range. He is a Maiatjara man, with strong ties with the Winanpa and Pintubi people. He has an exceptional knowledge of traditional ways and is an ever-cheerful person, a wonderful character.

- Charlie Tjararu Tjungurrayi was born c. 1924. His home country is in the Buck HillsDovers Hills area of Western Australia, west of the Ehrenberg Range. He identifies himself as a Pintubi, but has strong ties with the Maiatjara of the Kintore Range. He is a man of great intelligence with a ready wit, and a strong interest in traditional ways.

7 Nosepeg Tjupurrula was born c.1914 near Lake Macdonald, on the West Australian/ Northern Territory border. He is of the Winanpa tribe, and for 30 years has been one of the great ritual leaders of the Pintubi and Pintubi-related Aborigines. His knowledge of Aboriginal lore and law is unrivalled, and he has travelled as widely in the Western Desert as any other living person.

\section{BIBLIOGRAPHY}

Aborigines' Friends Association. 76th Annual Report. Adelaide, 1934.

Albrecht, F.W. 'Hermannsburg from 1926 to 1962' in Leske, Everard ed. Hermannsburg: a vision and a mission. Adelaide, 1977:42-90.

Blakeley, Fred. Dream millions: new light on Lasseter's lost reef. Sydney 1972.

Carnegie, David W. Spinifex and sand: a narrative of five years' pioneering and exploration in Western Australia. Ringwood, 1973.

Clune, Frank Last of the Australian explorers: the story of Donald Mackay. Sydney, 1942.

Connellan, E.J. Brief history of aviation in the Northern Territory. MS dated 20 May 1979. Copy held in Central Australian Aviation Museum files, Alice Springs, N.T.

Coote, Errol Hell's airport: the key to Lasseter's gold reef. Sydney, 1934.

Giles, Ernest. A ustralia twice traversed: the romance of exploration, being a narrative compiled from the joumals of five exploring expeditions into and through Central South Australia, and Westem Australia, from 1872 to 1876 . Sydney, 1979 (1 st published 1889). 
Idriess, Ion L. Lasseter's last ride: an epic in Central Australian gold discovery. Sydney, 1969. (1st published 1931).

Kimber, R.G. Private journals and tape-recordings, 1970-82. MSS in author's possession. Leske, Everard ed. Hermannsburg: a vision and a mission. Adelaide, 1977.

Lockwood, Douglas. The lizard eaters. Melbourne, 1964.

Long, J.P.M. 'The Pintubi patrols: welfare work with desert Aborigines', Australian Territories, $4(5), 1964: 43-48 ; 4$ (6) 1964:24-35.

Madigan, C.T. Central Australia. Melbourne, 1944. (1st published 1936).

Marshall-Stoneking, Billy. 'Around the hills of the giant men', Overland, 85, October 198 1:4046.

Tietkens, W.H. 'Journal of Mr W.H. Tietkens' Central Australian exploring expedition', in South Australia. Parliamentary Papers, v. 3. Adelaide, 1890.

Tindale, Norman B. Aboriginal tribes of Australia: their terrain, environmental controls, distribution, limits and proper names. Canberra, 1974. 2 vols. 